This is the final peer-reviewed accepted manuscript of:

Ferri, P., \& Zan, L. (2019). Accountability and patronage in extraordinary administrations: Evidence from Pompeii. Financial Accountability \& Management, 35(1), 72-89.

The final published version is available online at:

https://doi.org/10.1111/faam.12184

Rights / License:

The terms and conditions for the reuse of this version of the manuscript are specified in the publishing policy. For all terms of use and more information see the publisher's website.

This item was downloaded from IRIS Università di Bologna (https://cris.unibo.it/)

When citing, please refer to the published version. 


\title{
Accountability and patronage in extraordinary administrations: evidence from Pompeii
}

\begin{abstract}
Drawing on the concept of an accountability web, this paper analyses the two-year long extraordinary administration of the archaeological site at Pompeii, where the Italian Prime Minister appointed a special Commissioner to deal with the alleged decay of the site in July 2008. Findings shed light on critical issues related to the appointment of 'loyal experts' in terms of strong personalisation, short-term thinking, and the influence of the media in the administration of public services. Moreover, the paper introduces patronage accountability as a distinct accountability dimension that is characterised by a hierarchical and informal nature, and which cannot be accessed by those who are not part of the transaction. We add to the literature by identifying patronage accountability as a separate accountability dimension that conflicts with more common ones, and examine the implications of this practice for public administration.
\end{abstract}

\section{INTRODUCTION}

In July 2008, the Italian Prime Minister Silvio Berlusconi declared a one-year state of emergency at the UNESCO archaeological site of Pompeii, appointing a Commissioner with special administrative powers to deal with an alleged crisis. The 'emergency' was not caused by a sudden natural disaster, but by media outcry about lack of visitor services, theft of relics and broken toilets (Arachi, 2008; Feltri, 2008; see also Corte dei Conti, 2010; Camera dei Deputati, 2010a). The Commissioner was given part of the ordinary budget of the entity managing the site (€40 million), and the chance to set up his own team and to repeal part of the normative framework to solve the alleged emergency quickly.

In this article, we reconstruct the experience of the extraordinary administration of Pompeii by looking at how the overall system of accountability relationships changed during the extraordinary intervention (2008-2010). Despite its apparent singularity - an alleged emergency used to centralise powers in the hands of the executive - we believe that the case under investigation is relevant for two interrelated reasons. 
First, extraordinary regimes with temporarily appointed commissioners to substitute the ordinary administration are common in Italy in recent years. There have been 10,000 such regimes, according to the only available estimate, spanning from local government to hospitals and cultural organisations (Moussanet, 2005; Cassese, 2012, refers to it as a sort of "parallel administration"). Indeed, similar practices involving the delegation of power from politicians to 'loyal experts' are also common elsewhere. For instance, Boisot and Child (1988, 1996) illustrate a similar administrative practice with reference to the economic reforms of the 80 s and 90 s in China. Studies on Turkey, Greece and Latin American countries provide additional examples of patronage appointments as a key element in the context of growing of populism (Gordin, 2002; Selçuk, 2016; Pappas, 2014). By looking at Pompeii, we therefore try to understand at the micro level the functioning and implications of this thus far neglected form of highly personalised administration that clashes with the more widespread (somehow idealised?) conception of an instrumentally regulated bureaucracy, where impersonal logics rather than subjective judgments legitimise the action of the government (Mennicken \& Miller, 2012; Rose, 1991).

Second, the study has implications for the notion of accountability. When reconstructing the accountability relationships that bond key actors in the Pompeii's emergency, we realised that the accountability types outlined in the literature (i.e. administrative, professional, political, legal - see Bovens, 2006; Parker \& Gould, 1999; Sinclair, 1995) were only partially useful in explaining the relationship between the Prime Minister and the Commissioner appointed to solve the emergency. Hence, by drawing on the literature on political science and anthropology, in this paper we introduce the notion of patronage accountability, defined as an unequal, reciprocal and vertical relationship, which cannot be accessed by people who are not part of the face-to-face relationship between patron and client. Hence, the paper complements and problematises existing taxonomies of accountability types (Bovens, 2006; Sinclair, 1995; Parker \& Gould, 1999). In our view, the lack of attention to patronage accountability shows that, despite their claimed universality, taxonomies of accountability types are embedded in the context of modernised liberal democracies, where political patronage has been limited in the last century (Flinders, 2009; Porter, 1995). While it would be easy to treat patronage accountability as an exception, the existence of patronage appointments worldwide (Kopecký, Mair, \& Spirova, 2012) suggests that this notion could be relevant to achieve a more complete picture of accountability pressures in different contexts. 
The paper is structured as follows. In the next section, we position patronage relationships in the accountability debate. After the methodological section, we provide a longitudinal reconstruction of the whole experience of Pompeii's emergency, identifying main phases and turning points. Discussion and conclusion follow.

\section{POSITIONING PATRONAGE IN THE ACCOUNTABILITY DEBATE}

The underlying rationale of extraordinary interventions is that procedural administrative accountability - i.e. accountability dealing with legal concepts such as compliance and rulefollowing (Hood, 1995; Catasus \& Gronlund, 2005) - in certain situations can constrain effective decision making. Thus, waiving procedural accountability and decreasing the number of administrative levels involved (Fioritto, 2008) is seen as a way to empower decision makers and allow them to deliver the expected results quickly. On the other hand, commentators point out the potentially undemocratic nature of decision making under special Commissioners (Cassese, 2006; Fioritto, 2008). The image of a 'sultanate' or the metaphor of 18th-century absolute rulers have been frequently used to depict the Prime Minister's use of states of emergencies (Violante, 2010; Chiavello, 2010; Salvia, 2006). The same authors argue that appointing special Commissioners excludes citizens and lower-tier administrators, and without strong control systems, Commissioners may end up totally unaccountable, despite their great powers.

However, procedural accountability is just one of the many accountability demands characterising the administration of Pompeii, and the public sector generally. Studies of accountability emphasise that public employees typically operate in an accountability web, facing multiple sources of legitimate authority and competing expectations (Romzek, 2000; Bovens, 2006; Luke, 2010, Leagreid \& Neby, 2016; Bracci, 2009; Koppel, 2005). In this sense, there is no certainty that decreasing accountability for procedures leads to a result-oriented approach, or that this automatically implies the absence of any form of accountability. For instance, the debate on accountability in the public sector underlines the relevance of professional, political and legal accountability, in addition to more traditional hierarchical accountability forms (see Bovens, 2006; Sinclair, 1995; Parker \& Gould, 1999 for a detailed description of these forms). Accountability demands may vary in terms of intensity, formality, and direction (Gelfand, Lim, \& Raver, 2004; Bergsteiner \& Avery, 2009); they can address superiors within the organisational hierarchy - as in 
the case of administrative accountability for results - or peers, equals, stakeholders outside the hierarchy (as in the case of professional accountability: Bovens, 2006; Schillemans, 2008).

As Romzek (2000, p23) claims, different types of accountability create "a thick web of multiple, overlapping accountability relationships within which public administrators work". Due to these 'overlaps', public officials can experience multiple tensions, such as when professional values clash with managerial demands (Broadbent, Dietrich, \& Laughlin, 1996; Parker \& Gould, 1999). These tensions could intersect with conflicts between different levels of the administration, such as when a public administrator identifies more closely with the unit he or she manages at the local, level rather than with the public administration as a whole. Hence individuals are expected to prioritise, trade-off or combine multiple accountability demands operating at different levels.

All the aforementioned accountability dimensions and related tensions may be relevant in a context such as Pompeii, which is a complex organisational setting, where multiple activities are carried out (preservation, conservation, research, visitors' management) with the involvement of a plurality of stakeholders (local, national and supranational entities, visitors, archaeologists, and the media). It would be therefore naïve to believe that introducing a new administrative layer - the special administration - would automatically reduce the complexity of accountability relationships. Quite paradoxically, weakening accountability for procedures could reawaken other accountability demands, and create new conflicts and tensions.

While we agree with the idea that public officers operate in an accountability web and experience multiple pressures, we maintain that accountability types included in current taxonomies (i.e. administrative, professional, legal, political accountability) capture only some of the accountability pressures that may characterise an extraordinary administration.

One of the most distinctive feature of special administrations in Italy is that commissioners are directly appointed by the Prime Minister or other ministries, without any encumbrance in terms of due process or transparency (Flinders \& Matthews, 2010). This style of appointment is referred to as a patronage appointment, and reflects centralised powers in the executive (Flinders, 2009; Flinders \& Matthews, 2010; Kopecky \& Scherlis, 2010).

In countries like Denmark, Sweden, France and Germany patronage appointments at the top of the state ${ }^{1}$ are seen as a tool to "steer public bureaucracy so as to reach policy outputs closer to

\footnotetext{
${ }^{1}$ A discussion of patronage appointments at the bottom of the state and in low-skill position is out of the scope of our study.
} 
[governing parties]' preferences" (Di Mascio, 2014, p682). Rather than looking at this practice as evil, the appointment of 'loyal experts' has been recently reinterpreted as a resource for good governance, as it strengthens the link between citizens, politicians and the state administration, and enhances 'political accountability' in an increasingly fragmented administrative landscape (Bearfield, 2009; Flinders, 2009; Flinders \& Matthews, 2010; Kopecky \& Scherlis, 2010). However, in Italy (and also in other European and developing countries), patronage appointments in key positions have historically served an 'exploitative' function (Kopecky \& Scherlis, 2010; Kikert, 2007; Di Mascio, 2014; Grzymala-Busse, 2008). In these contexts, in fact, "party elites manage appointments for controlling public institutions in order to cement their own personal linkages with the state rather than building organizational links with society" (Di Mascio, 2014, p690). Rather than as a resource for good governance, patronage is therefore associated with "selective incentives, particularistic exchanges, clientelistic practices and the use of appointments as rewards for loyalty or payment of previous support” (Flinders \& Matthews, 2010, p641). To put it bluntly, as we move away from the institutional contexts described in Anglo-American management literature, the 'loyal expert' needs to be more loyal than expert to be appointed.

Patron-client relationships can be defined as unequal, vertical and reciprocal. For Kettering (1988, p425, see also Eisenstadt \& Roniger, 1980) on the one hand,

the patron uses patronage resources he himself owns or controls on behalf of his client: he assists and protects his clients, giving them material benefits, opportunities for career advancement, and protection from demands of others. Clientage, on the other hand, is the loyalty and service that a client owes a patron in return of for his protection and advancement.

The reciprocal, quid pro quo nature of patron-client relationships implies the presence of a further, specific kind of accountability (Goodell, 1995, p252): in patron-client relationships "a detailed ledger of services given and received is maintained", and if expectations are not met, the relationship terminates (Boissevain, 1966, p22).

Accountability in patronage (or patronage accountability) has the following distinctive features: it is highly hierarchical, as the patron wields power over the client; and informal, as it relies on trust and loyalty rather than universal and impersonal rules. Informality determines the 
instability and inaccessibility of the obligations' contents. First, the inability to codify agreed standards of conduct "opens the door to constant renegotiations and personalisation of power relationships" between patron and client (Boisot \& Child, 1988, p522). Second, informality limits information diffusion to face-to-face interactions characterised by asymmetry of power (Boisot \& Child, 1988, 1996). Hence, obligations are inaccessible by those who are not part of this interpersonal, local and particularistic agreement.

Interestingly enough, literature on accountability has developed a distinctive dimension to make sense of situations where patronage is functional to policy implementation - i.e. patronage as a resource for good governance (Flinders, 2009, Flinders \& Matthews, 2010). Indeed, political accountability refers to public officers being accountable to citizens either formally via executive or parliament, or informally via the media (Bovens, 2006; see also Parker \& Gould, 1999; Sinclair, 1995; Luke, 2010). However, political as well as administrative, professional, or legal accountabilities fall short in capturing how accountability works in patron-client relationships that characterise exploitative forms of patronage.

Indeed, if we compare patronage accountability with other forms of accountability, we notice that the mix between hierarchy and informality characterising the former sets it apart from administrative accountability, which is hierarchical and formal, and professional accountability, which is horizontal and informal. Moreover, in patronage accountability, one is accountable to a person with a name and a surname, rather than an impersonal organisational role (as in administrative accountability), a professional community (as in professional accountability), or a group of voters or a system of rules (as in political and legal accountabilities respectively). Lastly, patronage accountability is mainly a matter of oral communication: it leaves no written evidence in internal documentation, newspaper articles or academic treatises. This has implications for data collection and interpretation, as will be discussed in the next section.

\section{SOURCES AND ANALYTICAL APPROACH}

In the present study, patronage accountability represents an additional dimension that enriches the accountability demands influencing decision makers involved in the two-year emergency at Pompeii between 2008 and 2010. Our analysis seeks to uncover the role each accountability demand plays at different stages, how intense it is, and how it interacts with other pressures in the complex web of expectations characterising the public sector. 
The data collection process was carried out between September 2010 and July 2011. As a first step, we collected and analysed newspaper articles to understand the phases of the emergency and to pinpoint the social units involved. Then we identified three main groups of actors: those related to the ordinary administration (the Ministry of Culture and Superintendence); those related to the extraordinary administration (Council of Ministers, General Commission, first and second Commissioner); and other actors (the media, Court of Auditors). We then performed a systematic search for documents related to the 2008-10 period on different databases ${ }^{2}$ in order to understand the role of each actor during the emergency period. In this phase, we collected 12 ordinances and decrees issued by the Council of Ministers, as well as 10 Ministry of Culture press releases and 14 records of parliamentary debates. We identified additional relevant documentation from these documents, including a program of interventions written by the first Commissioner, a report written by the second Commissioner, and inquiries produced by the Court of Auditors (Corte dei Conti, 2010). At this point, document collection included 59 newspaper articles.

We supplemented this data with interviews with actors in the ordinary administration, the extraordinary administration, and others. Interviewees at the Superintendence included the Superintendent of Pompeii in charge from 1997 to 2009, the Superintendent in charge from 2009 to 2010, the human resources manager and the accounting office manager. We also interviewed the directors of Pompeii, Hercolaneum and Boscoreale, three of the five archaeological sites that make up the Superintendence (the other two are Oplontis and Stabia). At the ministerial level, we interviewed the General Director of the Ministry of Culture and the Director of the Department of Antiquities. Prior studies informed our knowledge of the administration of Pompeii (Zan, 2002; Guzzo, 2003, 2011; Ferri \& Zan, 2014, 2015).

In relation to the extraordinary administration, the first Commissioner who was in charge between July 2008 and February 2009 passed away in October 2009, but we interviewed his spokesperson. Unfortunately, the second Commissioner did not reply to interview requests. When he was in charge, however, he gave several interviews to newspapers and TV, which we collected,

\footnotetext{
${ }^{2}$ For Ministry of Culture press releases: http://www.benicurali.it/mibac/opencms/MiBAC/sitoMiBAC/MenuPrincipale/SalaStampa/ComunicatiStampa/index html; for ordinances and decrees: http://www.protezionecivile.gov.it/jcms/it/provvedimenti.wp;jsessionid=97ADC7B4211AC3C6F9D1E2E579DA092 8.worker1; for parliamentary debates: www.camera.it and www.senato.it; for newspaper articles: www.banchedati.ilsole24ore.com. Key words used: Pompei, emergenza, commissario, commissariamento [Pompeii, emergency, commissioner, commissariamento].
} 
as well as chapters of the final report by the second Commissioner. ${ }^{3}$ We interviewed two members of the General Commission: the Superintendent and the General Director of the Ministry of Culture. The head of the cabinet, a close aid of the Minister of Culture and also member to the General Commission, declined the interview.

Finally, to better understand the content of newspaper articles, we interviewed representatives of two national trade unions in relation to tensions with the workforce, two national archaeologists associations and one member of a non-profit organisation supporting the protection and promotion of Italy's cultural heritage.

The 14 interviews combine two approaches: a narrative approach (Czarniawska 1998; Jovchelovitch \& Bauer 2000) and a focused approach (Kenneth 1994). Each interview started by asking for personal accounts of the events before, during and after the emergency. Next, the interview focused on the interviewee's role and relationship to other actors. We asked specific questions about how decisions by others affected the interviewee (or how the interviewee's decisions affected others). Each interview was digitally recorded and transcribed.

Analysis took place in three partially overlapping stages. First, based on documents and interview data, we drafted a detailed chronology of events. This led to the identification of four main phases and three turning points. Each phase and turning point was consistent in terms of the social units involved (e.g. the second phase began when the second Commissioner was appointed and started influencing the administration of Pompeii).

Second, we investigated the expectation and obligations of each social unit using the accountability web conceptual framework (Gelfand, Lim, \& Raver, 2004; Bergsteiner \& Avery, 2009; Romzek, 2000; Bracci, 2009). We coded each accountability relationship by type, direction and intensity. Although the five accountability types developed by Bovens (2006) offered some guidance to label the relationships - i.e. political, administrative, professional, legal and social new forms of accountability relationships were allowed to emerge from the data. It is in this phase that patronage accountability started to emerge as a distinct accountability dimension. More specifically, by critically reflecting on the data-collection process we realised that our understanding of 'what happened and why' for some crucial turning points was highly dependent on the explanation of single individuals, as there were no written sources to be consulted. If these

\footnotetext{
${ }^{3}$ Only 43 out of the 126 project fiches listed in the index were available online on the Minister of Culture's website in January 2011. After our request to access the whole report, however, even the available parts were then removed and "disappeared".
} 
individuals were not willing to be interviewed, as actually happened with the Head of the Cabinet and the second Commissioner, there was no other way to obtain the information, apart from political gossip from other sources, which was impossible to triangulate. This suggested that the relationships between some key actors was not only hierarchical but also informal and inaccessible to those excluded from the face-to-face conversations.

Thanks to the analysis of the accounts produced by each actor, we found the phases and turning points were not only different in terms of the social units involved, but also in terms of the number, type, direction and intensity of the accountability relationships that bonded them together (see Figures 1-4 for a graphical representation of the accountability webs over time).

The final step built on previous ones, and analysed the tensions generated by each unit's multiple accountability relationships and reflected on how actors used they autonomy to trade off, prioritise and balance conflicting demands.

\section{ACCOUNTABILITY DIMENSIONS IN POMPEII'S EXTRAORDINARY ADMINISTRATION}

We analyse Pompeii's emergency in four phases (before the emergency; the first Commissioner's mandate; the second Commissioner's mandate; after the emergency) and three turning points (the declaration of emergency; the substitution of the first Commissioner; the end of the intervention).

\section{Phase 0: before the emergency}

The ancient Roman city of Pompeii covers an area of 440,000 square meters and it is administered by Superintendence of Naples and Pompeii. ${ }^{4}$ Almost three million people visit Pompeii every year, attracted by its unique and extraordinary cultural value. The appointment of a special commissioner in July 2008 did not happen in a void: the special administration became part of, and partially modified, an already established accountability web, which we describe in the next paragraph.

Unlike the majority of the Italian Superintendences, the Superintendence of Naples and Pompeii ${ }^{5}$ maintains financial, administrative and scientific autonomy from the Ministry of Culture,

\footnotetext{
5 This was the name of the entity in 2008, when the emergency was declared. The Superintendences of Naples and Pompeii were in fact merged in 2007. From January 2014, the two entities have been split again. The emergency was therefore declared in a situation of institutional uncertainty that is still ongoing.
} 
following a reform in 1997. The rationale of the reform was to empower professionals to implement a long-term vision for the conservation of the site and financial resources to implement that vision. The reform allows the Superintendence to approve conservation projects through its board of directors without waiting for ministerial approval, and to cover expenditures with ticket revenues. As a result, financial resources for conservation increased dramatically (from $€ 3$ million to $€ 21$ million per year). The new role of City Manager was also a central part of the reform: it would have introduced an empowered administrative director with managerial expertise to the Superintendence.

However, the reform did not include changes to sustain this organisational autonomy (Zan, 2002). First, the reform did not change human resources practices. Even after the reforms, the Ministry of Culture still managed personnel, which impeded the recruitment of key positions needed to plan and implement projects worth millions of euros. Second, public tender procedures remained unchanged. In order to spend its resources, the Superintendence had (and has) to comply with the code for the award of public works (Codice dei contratti pubblici di lavori, servizi, forniture), which is highly inadequate for uncertain and complex conservation projects (Guccio, Pignataro, \& Rizzo, 2012). This delayed the implementation of the much-needed conservation program (Ferri \& Zan, 2015).

From an accountability point of view, the relationship between the Superintendence and the Ministry of Culture remained ill defined. In fact, the reform did not create a link between autonomy and administrative accountability for results (Ferri \& Zan, 2014): within the organisational structure of the Ministry of Culture, the Superintendence was and still is only formally accountable for probity on the use of resources and procedural compliance to the Department of Antiquities. Consider for instance that in the 10 years after the reform, the Superintendence did not produce any annual report linking resources spent to achievements at the site (Ferri \& Zan, 2014). Instead, the Superintendence's archaeologists reported their activities only to peers (that is, other archaeologists) through a scientific publication - the Rivista di Studi Pompeiani (Pompeian Studies Review) - which fostered a form of professional and mutual accountability (Bovens, 2006).

Lacking administrative means to control the peripheral entity impersonally at a distance, throughout the years various Ministers of Culture enforced control by sending their 'loyal experts' to Pompeii: in fact, the selection process for the position of City Manager used criteria that could be characterised as political patronage rather than in terms of efficiency and effectiveness (Ferri \& 
Zan, 2014). More specifically, while the first City Manager was loyal and expert, the expertise of the second (a retired air force general) and third (an archaeologist with no experience in management) was repeatedly questioned in the press (e.g. Ranieri Panetta, 2007; Erbani, 2007).

Despite the poorly designed autonomy, and despite political influences, in the years following the reform the Superintendence achieved few relevant results. For instance, the number of areas open to the public increased and a more even distribution of visitors across the site was achieved thanks to the opening of new gates (see Ferri \& Zan, 2014). Quite surprisingly, however, a critical discussion of what did and did not work in the previous years was not part of the process that led to the appointment of the special Commissioner.

\section{Turning point 1: The declaration of the state of emergency}

Figure 1 shows the accountability web when the state of emergency was declared. As discussed above, the Ministry of Culture and the Superintendence are linked only by a hierarchical administrative accountability relationship for procedural compliance and probity on the use of resources. The link between the Superintendence and the professional community is relevant, as previous work in Pompeii reflected mainly the expectation of archaeologists. In the figure, the Council of Ministers is connected to the Superintendence only indirectly through the Ministry of Culture within the administrative apparatus of the state. Patronage accountability is not part of the picture because the highly politicised post of City Manager was abolished in 2007 following budget cuts at the ministerial level.

The role of the media and political accountability bonds are crucial to understanding why the intervention was launched in July 2008, and why it was framed as an emergency. In July 2008, the media presented a new wave of investigations into the situation at the site, pointing to lack of parking, poor conservation of historical buildings, theft of relics and lack of signs for visitors (Arachi, 2008). This created new tensions and renewed old ones within the accountability web.

For the Council of Ministers, the media's outcry created a tension between political and administrative accountability. The Council of Ministers needed to react, since the investigations occurred after the election of May 2008, and were thus a test for the new government coalition (the fourth Berlusconi cabinet). However, the Council was constrained by administrative accountability bonds. As per Figure 1, the Council was connected to the Superintendence only indirectly through the Ministry of Culture. The latter had never specified formal expectations about conservation 
standards or visitor services, holding the Superintendence accountable only for procedural compliance and probity on the use of resources. According to our interpretation, media criticism of the poor quality of visitor services fell outside what the Superintendence could be held responsible for by the Ministry of Culture, and, therefore, the Council.

Media critiques focused on the Superintendence, and confirmed a general misunderstanding about the difficulties in the years following the reforms (newspaper articles did not present any analysis of the causes of the decay). Part of the reason for this misunderstanding can be attributed to the Superintendence itself. The entity had used the decay argument to generate a broad consensus for its autonomy 10 years earlier (e.g. Oriani, 1996; Bobbio, 1998; Detheridge, 1998; see Zan, 2000 for a review) but in the following years it failed to communicate to a larger audience how its projects were effective in dealing with those issues, and what the constraints were, and instead it prioritised professional accountability (Ferri \& Zan, 2014). This fostered negative opinions about the management of the site, and led to public support for the extraordinary administration: the (few) critiques in the aftermath of the intervention focused on the modus operandi (i.e. declaration of a state of emergency), yet acknowledging the difficult conditions of the site (Senato della Repubblica, 2008, 2009). In other words, compared with phase 0 , the most important discontinuity here relates to changes in the perceived intensity of political accountability demands: at turning point 1, media relations were undertaken by the Council of Ministers directly, rather than being a part of the Superintendence's routines.

The state of emergency was therefore declared in a situation where there was little clarity about the expectations between different parties and about the administrative conditions necessary to achieve those expectations. However, rather than reducing the misalignment (Gelfand, Lim, \& Raver, 2004) by tightening the relationship between the Ministry and the Superintendence and/or by better designing the administrative conditions for the autonomy of the Superintendence, the Council took a shortcut and sent a Commissioner to Pompeii in the hope he could quickly fix many longstanding issues.

[Figure 1: Accountability web at turning point 1]

\section{Phase 1: The first Commissioner's term}

Through an ordinance, the Prime Minister appointed a special Commissioner, a former City Prefect, immediately after the declaration of the emergency (OPCM 3692/2008). Thanks to the 
emergency legislation, the appointment process was free from procedural constraints: the vacancy was not openly advertised, there was no job description nor independent scrutiny led by experts and/or an independent assessor (Flinders \& Matthews, 2010; see Sancino, Sicilia, \& Grossi, 2017 for a detailed description of selection criteria in public appointments).

In phase 1, some formal accountability connections remain unchanged. Figure 2 shows that the Council of Ministers, Ministry of Culture and Superintendence are still linked by hierarchical administrative accountability for input and probity on the use of resources. These links remain the same during and after the state of emergency, consistent with the non-reformative and temporary nature of emergency interventions.

Figure 2 also shows the formal changes introduced with the ordinance that appointed the first Commissioner (OPCM 3692/2008). In addition to the Commissioner himself, the ordinance introduced the General Commission for Direction and Coordination (General Commission hereafter). The General Commission was made up of the Superintendent, the head of the cabinet and the General Secretary of the Ministry of Culture, a member of the Campania region administration, and one expert appointed by Civil Protection, the agency responsible for emergency interventions at the national level (OPCM 3692/2008). The Commission's role was to support the Commissioner and to approve, verify and control operations at the site. Hence, at least on paper, the Commissioner and the Commission were linked by a high-intensity unidirectional administrative accountability for output.

Although broadly defined, the ordinance asked the Commissioner to work towards certain goals, namely safeguarding the archaeological area, removing illegal settlements located in or nearby the archaeological area, undertaking extraordinary maintenance, outsourcing surveillance, raising funds, and doing "whatever needed to overcome the emergency" (OPCM 3692/2008). The ordinance did not specify, however, what to prioritise, leaving it to the Commissioner's discretion. Moreover, the Commissioner could select his own staff and speed up administrative processes by repealing part of the normative framework, for example tender procedures and human resources management regulations (OPCM 3692/2008). The Commissioner had a budget of $€ 40$ million that had previously belonged to the Superintendence as a result of the financial autonomy obtained in 1997. Hence, while the Council of Ministers did not criticise the Superintendence openly at the time of the declaration of the state of emergency, the transfer of resources from the entity to the Commissioner can be read as a deceptive attempt to blame the former for the decay of the site. 
Once in Pompeii, the first Commissioner used most of his resources (91 per cent of $€ 40$ million) to support the implementation of conservation projects that were already planned by the Superintendence. Only a small part of the budget was allocated to so-called 'visitor-oriented' activities (toilet improvements, drinking fountains and public lighting) that both the media and the Council had called for. Thus, the Commissioner simply accelerated, rather than deeply transformed, the course of action already undertaken by the Superintendence.

To explain why the Commissioner used his power in this way, we need to understand the multiple accountability demands he was exposed to, and how he eventually decided to manage them. The administrative accountability link with the General Commission offers a first explanation. We need to recall that the Superintendent was part of the Commission. While the Superintendence had projects planned but no longer had the resources to undertake them, the Commissioner depended on the Superintendent to get his plan of interventions approved. In addition, the high-intensity, bidirectional professional accountability relationship between the Commissioner and his professional community may have had a role in this phase, as suggested by his spokesperson and the Superintendent of that time during interviews (the Commissioner passed away before the start of the data collection process). The first Commissioner was, in fact, a former Prefect, and it can be argued that this professional background influenced his approach to the emergency. Prefects are representatives of the state at the provincial level, and they ensure that tasks related to public order are carried out and coordinated between central and local governments. Part of an administrative elite (De Niccolò, Rolando, \& De Rita, 2009), they are trained within the central administration, especially in administrative law. Being, in the words of the former Superintendent of Pompeii "a bureaucrat accountable to bureaucrats", the Commissioner's view of the problems at Pompeii centred on administrative processes. As he had no training in archaeology, he did not challenge the decisions taken by the Superintendence on a technical level. According to his spokesperson, he created instead a team of experts in public procurement (SANP, 2008) and waived regulations to speed up the time-consuming procurement procedures the Superintendence had to follow. Hence, in this phase the accountability demands originating from the relationship between the Commissioner and the General Commission (administrative accountability), and the Commissioner and his peers (professional accountability) reinforced each other and shaped Pompeii's administration (a cooperation between the Commissioner and the Superintendent), and the focus of the activities (mainly conservation, and only in small part services to visitors). 
Paradoxically, the way the intervention unfolded in this phase shows how the Superintendence could have worked if the reform had granted a 'real' autonomy to the agency in 1997 (paradoxically because it took place under a state of emergency rather than being embedded in the design of the original reform). Indeed, the Commissioner had powers to hire personnel and to speed up tender procedures, which the Superintendence did not have in the late 1990s. A 'solution' to the shortcomings of the reform was achieved 10 years later in a totally unplanned way and, most importantly, under a temporary state of emergency. Or, in other words, by halting the autonomy of the Superintendence instead of completing the reform.

Despite the initial coverage of the emergency, the media only played a marginal role in shaping the intervention during the first phase of the implementation, which explains the exclusion of the media from Figure 2.

\section{Turning point 2: The substitution of the first Commissioner}

Evidence from the first phase would suggest the use of patronage appointment as an organisational and governmental resource (Bearfield, 2009; Flinders, 2009; Flinders \& Matthews, 2010; Kopecky \& Scherlis, 2010), whereby the management of a complex archaeological site is delegate to a trusted expert. However, and even without considering the provisional nature of the intervention, the fact that ensuring a sustainable change in the administration Pompeii was not part of the Council of Ministers' agenda is confirmed by its decision to replace the first Commissioner after eight months (OPCM 3742/2009). This was done without consulting the General Commission, and without formally assessing activities carried out at the site, as it emerges from interviews with two Commission's members. The substitution came as a surprise also to the Commissioner's staff. As his spokesperson said, "After the substitution was communicated [to the first Commissioner] during a closed-door meeting in Rome, I thought they would have produced some sort of justification. This did not happen. They discharged him without providing any". When interviewed, members of the General Commission and the Commissioner's staff said the substitution was a 'mystery'. No justification for the decision appears in the documents issued by or related to the Council of Ministers (media releases, interviews to newspapers, ordinances and decrees). Moreover, none of the newspapers published an independent analysis.

The substitution of the first Commissioner sheds light on the last connection in the accountability web during the first Commissioner's term. Besides the 'administrative 
accountability' and the 'professional accountability' relationships described above, there was also a perhaps more important patron-client bond linking, among others, the Commissioner and the members of the Council of Ministers that decided upon his appointment and then his substitution.

Patron-client relationships are defined as unequal, vertical and reciprocal (Kettering, 1988; Eisenstadt \& Roniger, 1980). In this relationship, reasons for conduct are still demanded and given (Goodell, 1995; Boissevain, 1966). However, as opposed to other forms of accountability, these reasons are almost impossible to ascertain by those excluded from the face-to-face interactions between accountee and accountor. Moreover, while the accountee's conduct is compared with professional standards in professional accountability or with performance indicators in administrative accountability (Bovens, 2006), in patronage accountability this lies with the subjective (and variable) preferences of the accountor.

It is impossible to comment on the 'real' reasons behind the substitution of the first commissioner, given the low information codification and diffusion characterising the relationship (Boisot \& Child, 1988), exemplified here by the closed-door meeting where the Commissioner was dismissed. Certainly they were not linked to the achievement of the ordinance's goal, towards which the Commissioner appears to have worked in a satisfactory way during his term (Ferri, 2016).

\section{Phase 2: The second Commissioner's term}

Similar to the first, the second Commissioner was appointed without any obligation in terms of transparency (Sancino, Sicilia, \& Grossi, 2017). At the time he was appointed, the second Commissioner was the general director of Civil Protection's emergency office. He had served as operating manager during emergencies such as earthquakes and, more importantly, he was responsible for organising major events in the country. ${ }^{6}$

Three important elements transformed the accountability web in this phase (see Figure 3). First, the Council of Ministers removed the voting right of the Superintendent within the General

\footnotetext{
${ }^{6}$ Since 2001, the responsibilities of the Italian Civil Protection have been extended to the planning and management of so called "Grandi Eventi" (big events). Several commissioners with special administrative powers have been appointed throughout the country to organise major sport and cultural events or international summits. This highly controversial practice terminated in 2012 following a reform of the Civil Protection. The reform was triggered by a major bribery scandal concerning the organisation and management of Big Events (the Swimming World Championship in Rome 2009 in particular).
} 
Commission (OPCM 3795/2009). This is shown in Figure 3 where there is no connection between the Superintendence and the Commission. Hence, while the autonomy of the first Commissioner was at least formally limited by the demands of the Superintendent, in addition to the informal process of 'respect' of professional knowledge by the first Commissioner, this constraint disappeared for the second Commissioner. The voice of archaeologists was therefore marginalised: as the interim Superintendent put it, "In the period I was in charge, I met [the second Commissioner] two times. He had his own program. There was no overlapping between his and my tasks".

Second, while the first Commissioner belonged to the administrative apparatus of the state and was professionally accountable to it, the second was linked to a different professional community. As an experienced event manager, his professional status derived from his expertise in promotion and communication, including (over) exposure to media.

This relates to the third link characterising the accountability web in this phase, namely the one between the second Commissioner and the media. In this phase in fact, and differently from before, the presence of the second Commissioner on newspapers and press releases was tireless, arguably because of a more active press office than because of an increased substantive interest in what was going on in Pompeii.

Overall, understanding the accountability web of this phase meant mainly listing the personal bonds of the Commissioner. After the exclusion of the Superintendent, the General Commission was transformed into an empty box, whose actual power was inversely proportional to the space the Commission and its members occupy in Figure 3.

Considered together, the weakening of the formal administrative accountability link and the self-reinforcing influence of professional, political and patronage accountabilities influenced the interventions implemented at the archaeological site. In contrast to the first Commissioner, the second Commissioner decided to invest most of the available resources (56 per cent of $€ 40$ million) in promotion and improving visitor services by developing his own projects, without integrating his program with the Superintendence's one. For instance, €3.1 million was invested in Pompeiviva, a new website and promotional video. The Commissioner also funded smaller projects such as exhibitions, writing contests, publications and theatre performances.

Gelfand, Lim and Raver (2004) use the concept of accountability web alignment to describe the degree to which individuals covering the same position experience similar accountability 
demands in terms of type, intensity and direction. For Pompeii's special Commissioners, there was low alignment, because the position they held did not define their accountability web. On the contrary, depending on the Commissioner, the overall accountability web changed. Moreover, the Commissioners' distinctive personal accountability links strongly influenced their understanding of what had to be done (conservation versus enhancement) and by whom (the Commissioner and the Superintendence versus the Commissioner alone). This is not a problem in itself, as low levels of alignment can increase flexibility to adapt to changes (Wright \& Snell, 1998). However, the Commissioners were not appointed or substituted because their bonds made them more or less fit to solve the problems for which they were nominated. Instead, authority was given or taken according to patron-client bonds that were closer to a non-transparent spoils system logic than a merit-based system.

[Figure 3: Accountability web in phase 2]

It is also important to note that during the second Commissioner's term the disempowering of formal administrative accountability went hand in hand with the decrease of the official documentation available. During the term of the first Commissioner, members of the Commissioner's staff and resource expenditure were documented, while for the second Commissioner clarifying these issues was either impossible or difficult. The second Commissioner did not agree to be interviewed, so the composition and competencies of his staff are still unknown. Regarding the investments, nothing but the narratives presented by the Commissioner himself to newspapers (i.e. Rissotti, 2010) were publicly available (and the second Commissioner's final report was only partially and temporarily accessible). The figures presented here rely on data obtained as a courtesy by the Superintendence, who had received them from the second Commissioner at the end of the state of emergency to manage pending payments (the file contained information about the amount, date, object of each cash outflow).

\section{Turning point 3: The end of the state of emergency}

The state of emergency was supposed to end on 30 June 2010. However, the Council of Ministers withdrew the emergency status 20 days earlier, on 10 June (DPCM 10/06/2010). The suspension ordinance made reference to a note presented by the Commissioner himself, where he declared that the interventions implemented were effective in countering the decay of the site (DPCM 
10/06/2010). Evidence from documents and interviews regarding this phase bring to the centre the Council of Ministers and its relationships with four main social units: the media, the Civil Protection, and the Court of Auditors (see Figure 4).

[Figure 4: Accountability web at turning point 3]

At the beginning, the media generally supported the intervention, but by 2010 their support dropped dramatically, which put the Council of Ministers and Civil Protection (the agency the second Commissioner belonged to) under fire for two main reasons. First, in January 2010 a small crane collapsed on an ancient building in Pompeii. According to the non-government organisation that exposed the incident to the media, the causes were related to the speed and lack of proper precautionary measures in the restoration works carried out by the second Commissioner (see Camera dei Deputati, 2010b). Second, a national scandal involving bribery during emergency interventions exploded in February 2010. This largely discredited emergency interventions, in particular Civil Protection's officers like the second Commissioner, throughout the country. All this considered, in terms of political accountability, the special administration of Pompeii started to become a source of problems, rather than consensus from the Council of Ministers' perspective.

Moreover, in February 2010 the Court of Auditors started investigating the legal legitimacy of the emergency in Pompeii. The Court asked the Council of Ministers and Civil Protection to justify why the situation of Pompeii in July 2008 was represented as an emergency. At the end of the investigation, the Court argued that many activities carried out by the two Commissioners, such as the promotion of the site or the organisation of theatre performances, were not consistent with the legal definition of 'emergency intervention' (Corte dei Conti, 2010). In a rather determined way, the Court declared the intervention illegitimate in August 2010. ${ }^{7}$

Under pressure both from the point of view of political accountability in relation to the media and legal accountability in relation to the Court of Auditors' investigation, the Prime Minister decided to terminate the emergency irrespective of the evaluation of the General Commission, which was not involved in the decision according to the Commission's members interviewed. This was the last of a series of decisions downplaying administrative accountability for results. To put it more radically, the emergency administration ended not because the issues that motivated the

\footnotetext{
${ }^{7}$ Curiously enough, the Court of Auditors did not apply any sanction because the state of emergency had already been declared over.
} 
intervention were solved, but as a consequence of a complex interplay between administrative, legal and political failures. Although the special administration turned out to be a failure, and despite the second Commissioner being under investigation for breach of trust and forgery in relation to the award of public services contracts during Pompeii's emergency (Vera, 2015), the Prime Minister appointed him as one of the national coordinators of his political party (Forza Italia) after the end of the emergency (Fantauzzi, 2013). The second Commissioner may have failed as an expert, but he was loyal, and this is what counts the most in patron-client relationships.

\section{Phase 3: Back to business as usual}

The reason we described phase 0 in such detail is because the intervention has changed nothing (see Figure 5 for a summary of the evolution of Pompeii's emergency). The Superintendence personnel interviewed agreed, saying that the short-term projects with high media impact (concert, PR initiatives) implemented during the second Commissioner's term ended with the termination of the emergency, and did not become part of the routine of the Superintendence afterwards. In addition, in our view the focus on problems such as the lack of toilets shifted attention away from a crucial issue: the causes of the failure of the reform of the Superintendence of Pompeii launched in 1997. Ferri and Zan $(2014 ; 2015)$ observe this was due, among other things, to the rigidity of public procurement procedures that delayed conservation projects and caused underspending, and to the underdevelopment of administrative accountability for results. The latter would have had a double function: it made those who were managing the site responsible (i.e. the Superintendents and the archaeologists) and regulated the relationship between the Superintendence and the ministerial apparatus, which limited the interference of politicians. After two years of emergency, none of the aforementioned issues has changed: the formal relationship between the Ministry of Culture and the Superintendence is still based on administrative accountability for procedures and probity on the use of resources; the archaeological community continues to be the main reference point for archaeologists working at Pompeii.

\section{DISCUSSION AND CONCLUSION}

It is not our intention to uncritically generalise our findings about Pompeii to special administrations in all types of different settings. However, the critical absence of accountability for results, the presence of patronage logics, short-term thinking and an inability to change constitute 
a first point of reference for those interested in investigating the many extraordinary regimes in Italy. We also believe our study has broader implications for the debate on patronage appointments in public administration, the study of accountability and change.

Some authors claim that patronage appointments are not always evil, but can become a tool for good governance if criteria of merit, openness and transparency are used during the selection process (Bearfield, 2009; Flinders \& Matthews, 2010). For instance, Sancino, Sicilia and Grossi (2017) show that independent scrutiny improves the perception of integrity and fairness when politicians appoint public officers. Having analysed a case of worst practice related to patronage appointments, our study confirms the importance of explicit standards and frameworks in appointing, removing or confirming 'loyal experts'. At the same time, the study complements this debate by moving the attention from the appointment process to what appointees actually do (and report) during their terms. In this regard, the study underlines the importance of designing effective administrative accountability systems to counterbalance patronage accountability pressures. As we have shown, in fact, if organisational arrangements fostering codification and diffusion of information (Boisot \& Child, 1988, 1996) are not introduced (none of the Commissioners produced a publicly available final report), secrecy may extend from the appointment process to the actual administration of a public service. The related risk is that directly appointed officials manage public administrations in a highly personalistic and short-term way, taking decisions aimed at securing the next appointment rather than improving the overall effectiveness of service.

The study introduced patronage accountability as a distinct form of accountability, specifying its distinctive features, namely its hierarchical and informal nature, and the fact that the content of obligations remain inaccessible to those who are not part of the transaction. Interestingly enough, patronage accountability is positioned outside the continuum that sees forms of control over delegation ranging from trust-based and horizontal to metrics-based and hierarchical (Laughlin, 1996; Roberts \& Scapens, 1985; Roberts, 1996; Catasus, 2008; Romzek, LeRoux, \& Blackmar, 2012; Kastberg, 2017). It also finds no place in more complex matrix-like taxonomies, distinguishing accountability types in terms of whether demands relate to values or results, and whether who is called accountable is an individual or a group or a community (see Lindkvist \& Llewellyn, 2003). One could wonder why patronage accountability does not represent an option in available systematisations of accountability types. There are, in our view, two possible, nonalternative, explanations. The first is that theoretical research in accountability has been developed 
by authors from and with reference to contexts where patronage appointments are narrow and aimed at policy implementation, mainly the UK (see Flinders, 2009 for a detailed discussion on the features of patronage appointments in this country). In these contexts, if something like patronage accountability existed, it surely belonged to the past, and was overcome by modern and impersonal bureaucracies (Rose \& Miller, 1992; Porter, 1995). Yet in many parts of the world, Italy included, patronage accountability explains more organisational behaviour than other public-sector accountability pressures.

The second reason may relate to the method used to analyse multiple accountability demands. Studies on this issue are in fact often based on perceived accountability pressures elicited via interviews (Luke, 2010; Bracci, 2009; Kastberg, 2016). But patronage accountability is difficult to uncover as officials are reluctant to discuss this topic, given the negative connotation for public opinion. As Freedman (1994, p vii) puts it, "no-one wants to admit a practice that bears the taint of corrupt machine politics". In the present study, however, we focused on actual accountability rather than perceived accountability. In other words, we tried to understand what explanations were given by key actors about specific decisions, and we critically reflected on the nature of the explanations and their availability. Patronage accountability emerged as a residual category, when all other possible explanations were ruled out (remember the substitution of the first Commissioner). In conclusion, patronage accountability may have been overlooked in the past not just because it is supposedly not an issue in modernised countries, but also because it rarely emerges from interviews.

Our last discussion point refers to the concept of an accountability web, and how it was used to make sense of change during the evolution of Pompeii's emergency. The concept helped to map the connections between the main actors, understand their strengths, and pinpoint the tensions originating in multiple connections. However, as opposed to prior studies that used the accountability web concept to map expectations and obligations among social actors at a specific time (see Bracci, 2009 for schools, or Bergsteiner \& Avery, 2009 for private prisons), we observe the evolution of an accountability web over time, trying to assess how a process of reform unfolded. Eventually, it was the way actors used their agency to prioritise or combine specific accountability demands that determined the evolution of the extraordinary intervention. We thus demonstrate that rather than being a static concept, the notion of an accountability web can become a powerful tool 
Accountability and patronage

to understand change if complemented by a focus on the autonomy of the social units comprising a web. 
Bergsteiner, H., \& Avery, G. C. (2009). A generic multiple constituency matrix: Accountability in private prisons. Journal of Public Administration Research and Theory, 19(3), 631-660. https://doi.org/10.1093/jopart/mun011

Boisot, M., \& Child, J. (1988). The iron law of fiefs: Bureaucratic failure and the problem of governance in the Chinese economic reforms. Adminstrative Science Quarterly, 33(4), 507527.

Boisot, M., \& Child, J. (1996). From fiefs to clans and network capitalism: Explaining China emerging economic order. Administrative Science Quarterly, 41(4), 600-628.

Boissevain, J. (1966). Patronage in Sicily. Man, New Series, 1(1), 18-33.

Bovens, M. (2006). Analysing and assessing public accountability. A conceptual framework. European Governance Papers (EUROGOV) No. C-06-01, 13(4), 1-37. https://doi.org/10.1111/j.1468-0386.2007.00378.x

Bracci, E. (2009). Autonomy, responsibility and accountability in the Italian school system. Critical Perspectives on Accounting, 20(3), 293-312. https://doi.org/10.1016/j.cpa.2008.09.001

Bracci, E., \& Llewellyn, S. (2012). Accounting and accountability in an Italian social care provider: Contrasting people- changing with people-processing approaches. Accounting, Auditing \& Accountability Journal, 25(5), 806-834. https://doi.org/http://dx.doi.org/10.1108/09564230910978511

Broadbent, J., Dietrich, M., \& Laughlin, R. (1996). The development of principal - agent , contracting and accountability relationships in the public sector: Conceptual and cultural problems. Critical Perspectives on Accounting, (7), 259-284.

Cassese, S. (2005). I paradossi dell'emergenza. In Annuario 2005 - Il Diritto Amministrativo dell'Emergenza. Milano: Giuffrè.

Cassese, S. (2012). L'Italia: una Società senza Stato? Bologna: Il Mulino.

Catasus, B., \& Gronlund, A. (2005). More peace for less money: Measurament and accountabiliy in the Swedish Armed Forces. Financial Accountability \& Management, 21(4), 467-484.

Cerase, F. P., \& Vivo, P. De. (2000). Shifts in autonomy, responsibility and control from centre to periphery in public administration: The case of the Ministry of Finance in Italy, 16, 411413.

Chiavello, D. (2010). L'Amministrazione dell'Ordinaria Emergenza. Retrieved March 16, 2015, from http://www.federalismi.it/nv14/articolodocumento.cfm?Artid=16387\&content $=$ L\%27amministrazione+dell\%27ordinaria+emergen za\&content_author=Debora+Chiaviello

Czarniawska, B. (1998). A Narrative Approach to Organization Studies. Thousand Oaks: Sage Publications.

De Niccolò, M., Rolando, S., \& De Rita, G. (2009). I Prefetti in Età Repubblicana. Un'èlite Amministrativa della Repubblica. Roma: Queste Istituzioni Ricerche.

Di Mascio, F. (2014). Exploring the link between patronage and party institutionalization: An historical-institutional analysis of the Italian transition. Democratization, 21(4), 678-698. https://doi.org/10.1080/13510347.2013.764286

Eisenstadt, A. S. N., \& Roniger, L. (1980). Patron-client relations as a model of structuring social exchange. Comparative Studies in Society and History, 22(1), 42-77.

Ferri, P. (2016). I Commissariamenti nel Settore Culturale Italiano. Obiettivi azioni risultati. Napoli: Editoriale Scientifica.

Ferri, P., \& Zan, L. (2014). Ten years after: The rise and fall of managerial autonomy in Pompeii. Critical Perspectives on Accounting, 25(4-5), 368-387. 
https://doi.org/10.1016/j.cpa.2013.05.007

Ferri, P., \& Zan, L. (2015). Partnerships for heritage conservation: Evidence from the archeological site of Herculaneum. Journal of Management \& Governance. https://doi.org/10.1007/s10997-015-9332-2

Fioritto, A. (2012). L'Amministrazione dell'Emergenza tra Autorità e Garanzie. Bologna: Il Mulino.

Flinders, M. (2009). The politics of patronage in the united kingdom: Shrinking reach and diluted permeation. Governance, 22(4), 547-570. https://doi.org/10.1111/j.1468-0491.2009.01453.x

Flinders, M., \& Matthews, F. (2010). Think again: Patronage, governance and the smarter state. The Policy Press, 38(4), 639-657.

Gelfand, M. J., Lim, B. C., \& Raver, J. L. (2004). Culture and accountability in organizations: Variations in forms of social control across cultures. Human Resource Management Review, 14(1), 135-160. https://doi.org/10.1016/j.hrmr.2004.02.007

Goodell, G. E. (1985). Paternalism, patronage, and potlatch: The dynamics of giving and being given to. Current Anthropology, 26(2), 247-266.

Gordin, J. P. (2002). The political and partisan determinants of patronage in Latin America 1960 - 1994: A comparative perspective, 41, 513-549.

Grzymala-Busse, A. (2008). Beyond clientelism incumbent state capture and state formation, 41(4/5), 638-673. https://doi.org/10.1177/0010414007313118

Guccio, C., Pignataro, G., \& Rizzo, I. (2012). Evaluating the efficiency of public procurement contracts for cultural heritage conservation works in Italy. Journal of Cultural Economics, 38(1), 43-70. https://doi.org/10.1007/s10824-012-9194-2

Guzzo, P. G. (2003). Pompei 1998-2003. L'Esperimento dell'Autonomia. Roma: Mondadori Electa.

Guzzo, P. G. (2011). Pompei, tra la Polvere degli Scavi. Essere Soprintendente a Pompei: Memorie Umane e Professionali. Napoli: Valtrend.

Hood, C. (1995). The "New Public Management" in the 1980s: Variations on a theme. Accounting, Organizations and Society, 20(2-3), 93-109. https://doi.org/10.1016/03613682(93)E0001-W

Jovchelovitch, S., \& Bauer, M. W. (2000). Narrative interviewing. In M. W. Bauer \& G. Gaskell (Eds.), Qualitative Researching with Text, Image and Sound: a Practical Handbook. London: Sage Publications.

Kastberg, G. (2016). Trust and control in network relations: A study of a public sector setting. Financial Accountability and Management, 32(1), 33-56. https://doi.org/10.1111/faam.12079

Kenneth, D. B. (1994). Interview studies. In D. B. Kenneth (Ed.), Methods of Social Research. New York: The Free Press.

Kettering, S. (1988). The historical development of political clientelism. The Journal of Interdisciplinary History, 18(3), 419-447.

Kopecký, P., Mair, P., \& Spirova, M. (2012). Party Patronage and Party Government in European Democracies. Oxford: Oxford University Press.

Kopecky, P., \& Scherlis, G. (2008). Party patronage in contemporary Europe. European Review, 16(3), 355-371. https://doi.org/10.1017/S1062798708000306

Koppell, J. G. S. (2005). Pathologies of accountability: ICANN and the challenge of "multiple accountabilities disorder." Public Administration Review, 65(1), 94-108. https://doi.org/10.1111/j.1540-6210.2005.00434.x

Lægreid, P., \& Neby, S. (2016). Gaming, accountability and trust: DRGs and activity-based 
funding in Norway. Financial Accountability and Management, 32(1), 57-79. https://doi.org/10.1111/faam.12080

Lindkvist, L., \& Llewellyn, S. (2003). Accountability, responsibility and organization. Scandinavian Journal of Management, 19(2), 251-273. https://doi.org/10.1016/S09565221(02)00027-1

Luke, B. (2010). Examining accountability dimensions in state-owned enterprises. Financial Accountability \&Management, 26(2), 134-162.

Mennicken, A., \& Miller, P. (2012). Accounting, territorialization and power. Foucault Studies, 97(13), 4-24.

Moussanet, M. (2005). Italia inefficiente: Diecimila commissari per l'ordinaria emergenza. Sole 24 Ore.

Pappas, T. (2014). Populism and Crisis Politics in Greece. Basingstoke: Palgrave Macmillan.

Parker, L., \& Gould, G. (1999). Changing public sector accountability: Critiquing new directions. Accounting Forum, 23, 109-135. https://doi.org/10.1111/1467-6303.00007

Porter, T. (1995). Trust in Numbers: The Pursuit of Objectivity in Science and Public Life. Princeton: Princeton University Press.

Romzek, B. S. (2000). Dynamics of public sector accountability in an era of reform. International Review of Administrative Sciences, 66(100), 21-44. https://doi.org/10.1177/0020852300661004

Romzek, B. S., Leroux, K., \& Blackmar, J. M. (2012). A preliminary th eory of informal accountability among network organizational actors. Public Administration Review, 72(3), 442-453. https://doi.org/10.111/j.1540-6210.2012.02547.x.Th

Rose, N. (1991). Governing by numbers: Figuring out democracy. Accounting, Organizations and Society, 16(7), 673-692.

Rose, N., \& Miller, P. (1992). Political power beyond the State: problematics of government. The British Journal of Sociology, 43(2), 173-205. https://doi.org/10.1111/j.14684446.2009.01247.x

Salvia, F. (2005). Il diritto amministrativo e l'emergenza derivante da cause e fattori interni all'amministrazione. In Associazione Italiana dei Professori di Diritto Amministrativo (Ed.), Annuario 2005 - Il Diritto Amministrativo dell'Emergenza. Roma: Giuffrè.

Sancino, A., \& Grossi, G. (2017). Between patronage and good governance: Organizational arrangements in (local ) public appointment processes. https://doi.org/10.1177/0020852316675944

Schillemans, T. (2008). Accountability in the shadow of hierarchy: The horizontal accountability of agencies, 8, 175-194. https://doi.org/10.1007/s11115-008-0053-8

Selçuk, O. (2016). Strong presidents and weak institutions: Populism in Turkey, Venezuela and Ecuador. Southeast European and Black Sea Studies, 16(4), 571-589. https://doi.org/10.1080/14683857.2016.1242893

Sinclair, A. (1995). The chameleon of accountability: Forms and discourses. Accounting, Organizations and Society, 20(2-3), 219-237. https://doi.org/10.1016/0361-3682(93)E0003Y

Violante, L. (2010). Prefazione. In Emergenza! Protezione Civile e Democrazia. Milano: Guerini e Associati.

Wright, P. M., \& Snell, S. A. (1998). toward a unifying framework for exploring fit and flexibility in strategic human resource management. Academy of Management Review, 23(4), 756-772.

Zan, L. (2002). Renewing pompeii, year zero. Promises and expectations from new approaches to 
museum management and accountability. Critical Perspectives on Accounting, 13(1), 89137. https://doi.org/10.1006/cpac.2001.0484

\section{PRIMARY SOURCES QUOTED IN THE TEXT}

Arachi, A. (2008), Furti, vandali e rifiuti. Il degrado di Pompei. Corriere della Sera, 03 July 2008. Bobbio, L. (1998), Per l'autonomia progettata. Il Sole 24 Ore, 24 May, 1998, p. 38.

Camera dei Deputati (2010a), Informativa urgente del Governo sul crollo della scuola dei gladiatori presso gli scavi di Pompei del 10 novembre 2010.

Camera dei Deputati (2010b), Elementi e iniziative in merito al recente crollo di un muro perimetrale nell'ambito degli scavi archeologici di Pompei, denunciato dall'associazione ambientalista Italia nostra - n. 2-00592.

Camera dei Deputati (2010c), Mozione 1-00491 dell'11 novembre 2010.

Corte dei Conti (2010), Deliberazione n. 16/2010/P. Retrieved December 12, 2010 from http://www.corteconti.it/controllo/cultura_istruzione_ricerca/beni_attivita_istituzioni/delibe ra_16_2010_p/.

Decreto del Presidente del Consiglio dei Ministri 04/07/2008, Dichiarazione dello stato di emergenza in relazione alla situazione di grave pericolo in atto nell'area archeologica di Pompei. (DPCM 04/07/2008).

Decreto del Presidente del Consiglio dei Ministri 10/06/2010, Revoca dello stato di emergenza in relazione alla situazione di grave pericolo in atto nell'area archeologica di Pompei. (DPCM 10/06/2010).

Detheridge, A. (1998). Alla sfida di Pompei guarda tutta 1'Europa. Il Sole 24 Ore, 5 April.

Erbani F. (2007) Nomine agli scavi polemica a Pompei. La Repubblica, 10 September 2007.

Retrieved August 28, 2017 from

http://ricerca.repubblica.it/repubblica/archivio/repubblica/2007/10/10/nomine-agli-scavipolemica-pompei.html.

Fantauzzi, P. (2013). Marcello Fiori, dal flop di Pompei ai club di 'Forza Silvio'. L'Espresso, 11 december 2013. Retrieved August 28, 2017 from:

http://espresso.repubblica.it/palazzo/2013/12/11/news/marcello-fiori-dal-flop-di-pompei-aiclub-di-forza-silvio-1.145418.

Feltri, M. 2008. Ora i manager alla cultura. La Stampa, 01 September, p. 10.

Ministero per i Beni e le Attività Culturali (Mibac) (2010), 'Mibac su appello 600 tecnici'. Retrieved December 13, 2010 from http://www.benicurali.it/mibac/opencms/MiBAC/sitoMiBAC/MenuPrincipale/SalaStampa/ComunicatiStampa/index.html.

Ordinanza del Presidente del Consiglio dei Ministri del 18/02/2009 n. 3742, Disposizioni urgenti di protezione civile. (OPCM 3742/2009).

Ordinanza del Presidente del Consiglio dei Ministri del 30/07/2009 n. 3795, Ulteriori interventi urgenti di protezione civile diretti a fronteggiare la grave situazione di pericolo in atto nell'area archeologica di Pompei. (OPCM 3795/2009).

Ordinanza del Presidente del Consiglio dei Ministri n. 3692 del 11/07/2008, Interventi urgenti di protezione civile diretti a fronteggiare la grave situazione di pericolo in atto nell'area archeologica di Pompei. (OPCM 3692/2008).

Oriani, R. (1996). Dossier Pompei. Reset, September. 
Ranieri Panetta M. (2007), Pompei a orologeria. L'Espresso, 05 April 2007. Retrieved August 28, 2017 from http://espresso.repubblica.it/palazzo/2007/04/05/news/pompei-aorologeria1.3145.

Rissotti, L. (2010). Fiori tra le rovine. Il Giornale dell'Arte, 08 September. Retrieved December 15, 2010 from http://ilgiornaledellarte.com/articoli//2010/9/103851.html.

Senato della Repubblica. (2009). Resoconto stenografico della seduta n. 157 del 24/02/2009.

Available at: http://www.senato.it/japp/bgt/showdoc/

frame.jsp?tipodoc $=$ Resaula\&leg=16\&id=396333. (Accessed on 15/12/2010).

Senato della Repubblica. (2008). Resoconto stenografico della seduta n. 93 del 18/11/2008. Senato della Repubblica. Retrieved December 15, 2010 from http://www.senato.it/japp/bgt/showdoc/ frame.jsp?tipodoc $=$ Resaula\&leg $=16 \& i d=00319338 \&$ part $=$ doc_dc $\&$ parse $=$ no.

Soprintendenza Speciale per i Beni Archeologici di Napoli e Pompei (2008), Primi provvedimenti del Commissario Profili a Pompei. Retrieved December 13, 2010 from http://www.pompeiisites.org/Sezione.jsp?titolo=primi\%20provvedimenti\%20del\%20Commi ssario\%20profili\%20a\%20pompei\&idSezione=1936. (SANP, 2008).

Vera, V. (2015). Pompei, sequestro di beni all'ex commissario Fiori per i lavori al Teatro Grande. Il Sole 24 Ore, 04 March 2015. Retrieved August 28, 2017 from http://www.ilsole24ore.com/art/impresa-e-territori/2015-03-04/pompei-sequestro-beni-allex-commissario-fiori-i-lavori-teatro-grande-121600.shtml?uuid=ABcL8x3C. 
Figure 1: Accountability web at turning point 1, July 2008

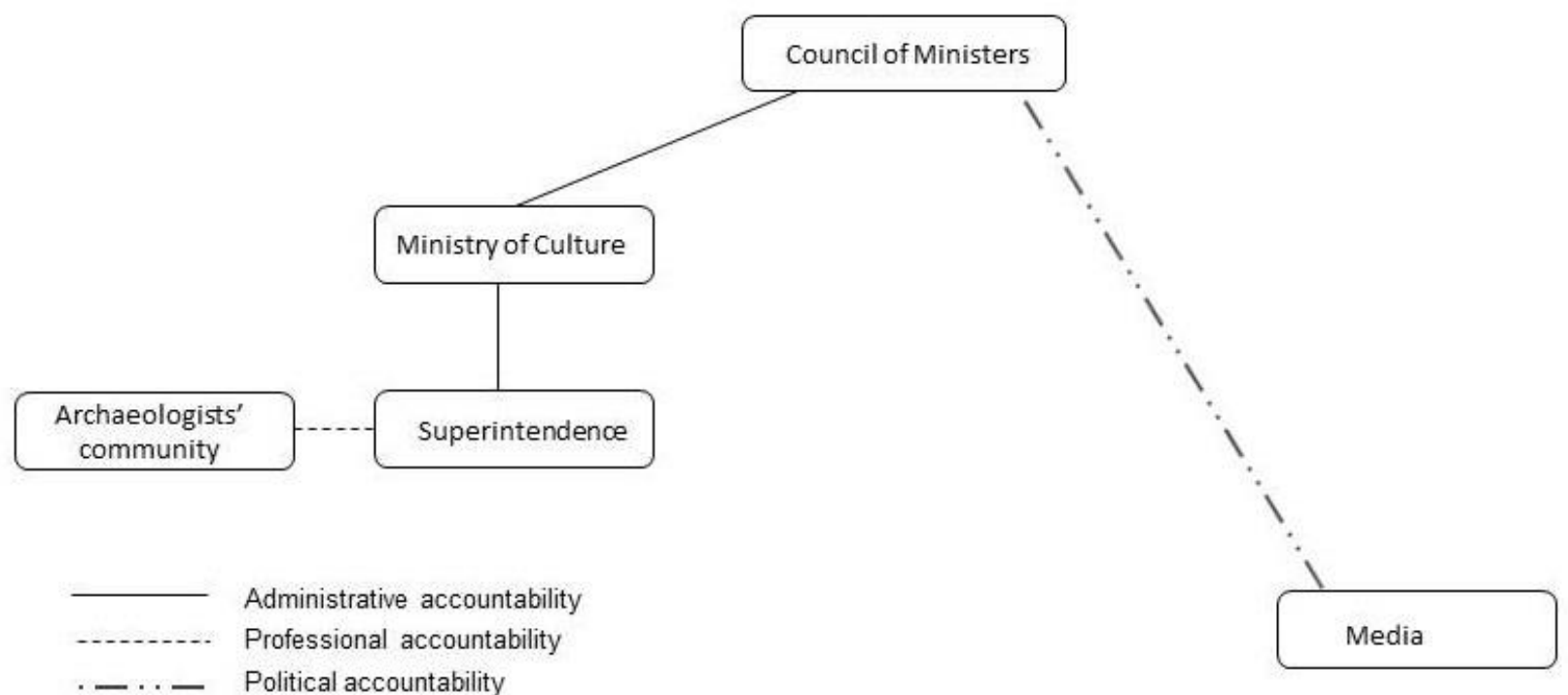

Figure 2: Accountability web in phase 1, July 2008-February 2009

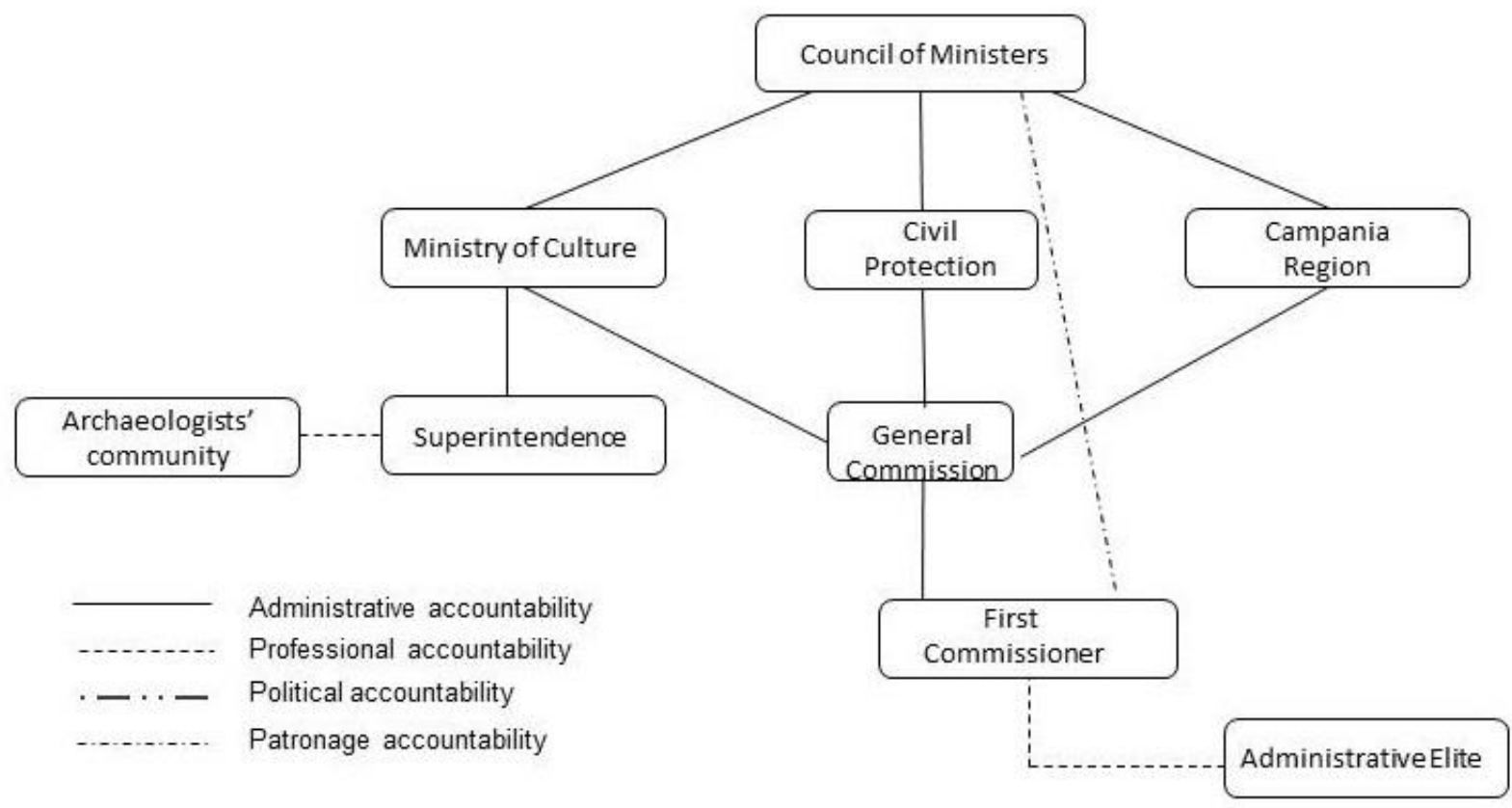


Figure 3: Accountability web in phase 2, February 2009-June 2010

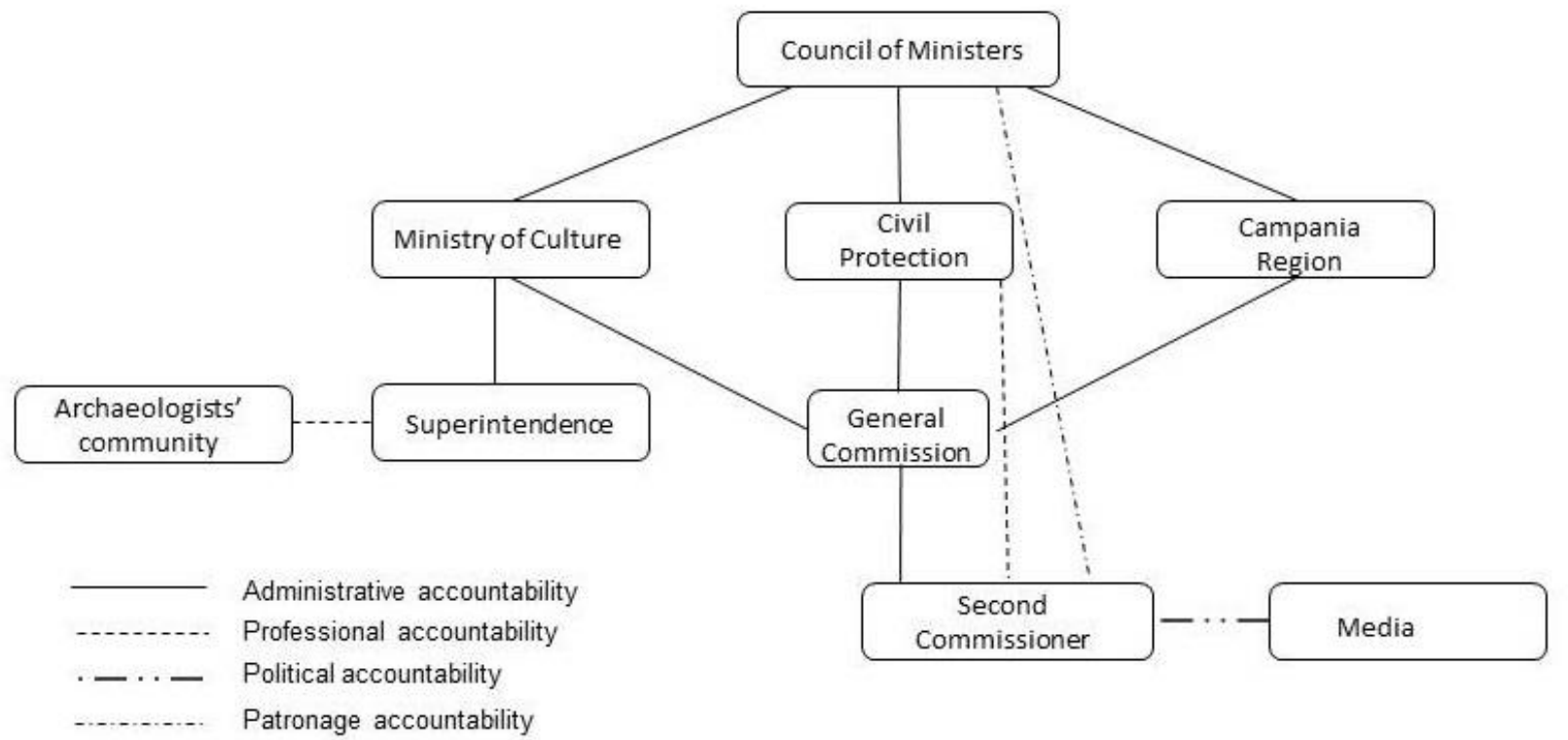

Figure 4: Accountability web at turning point 3, June 2010

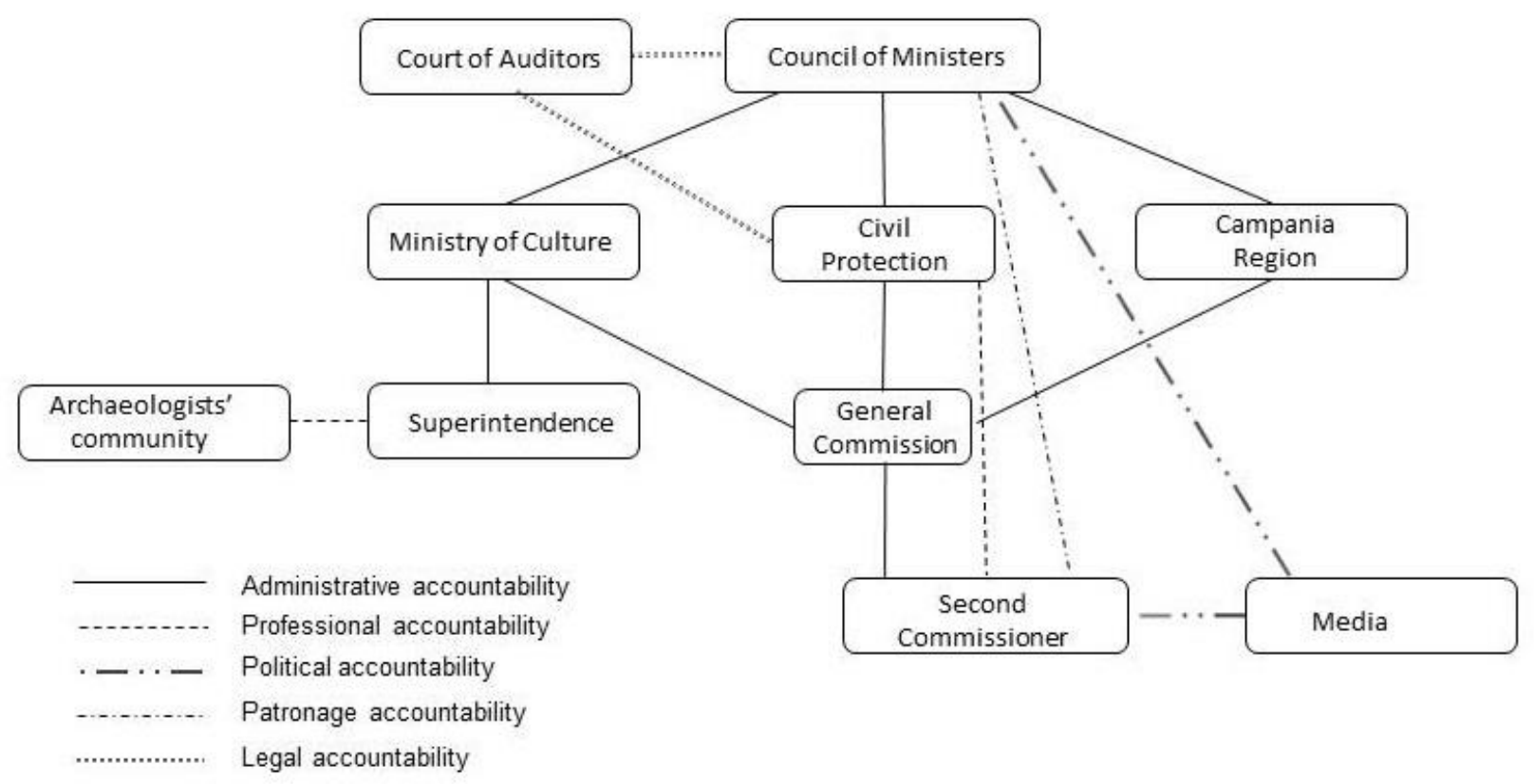


Figure 5: Summary

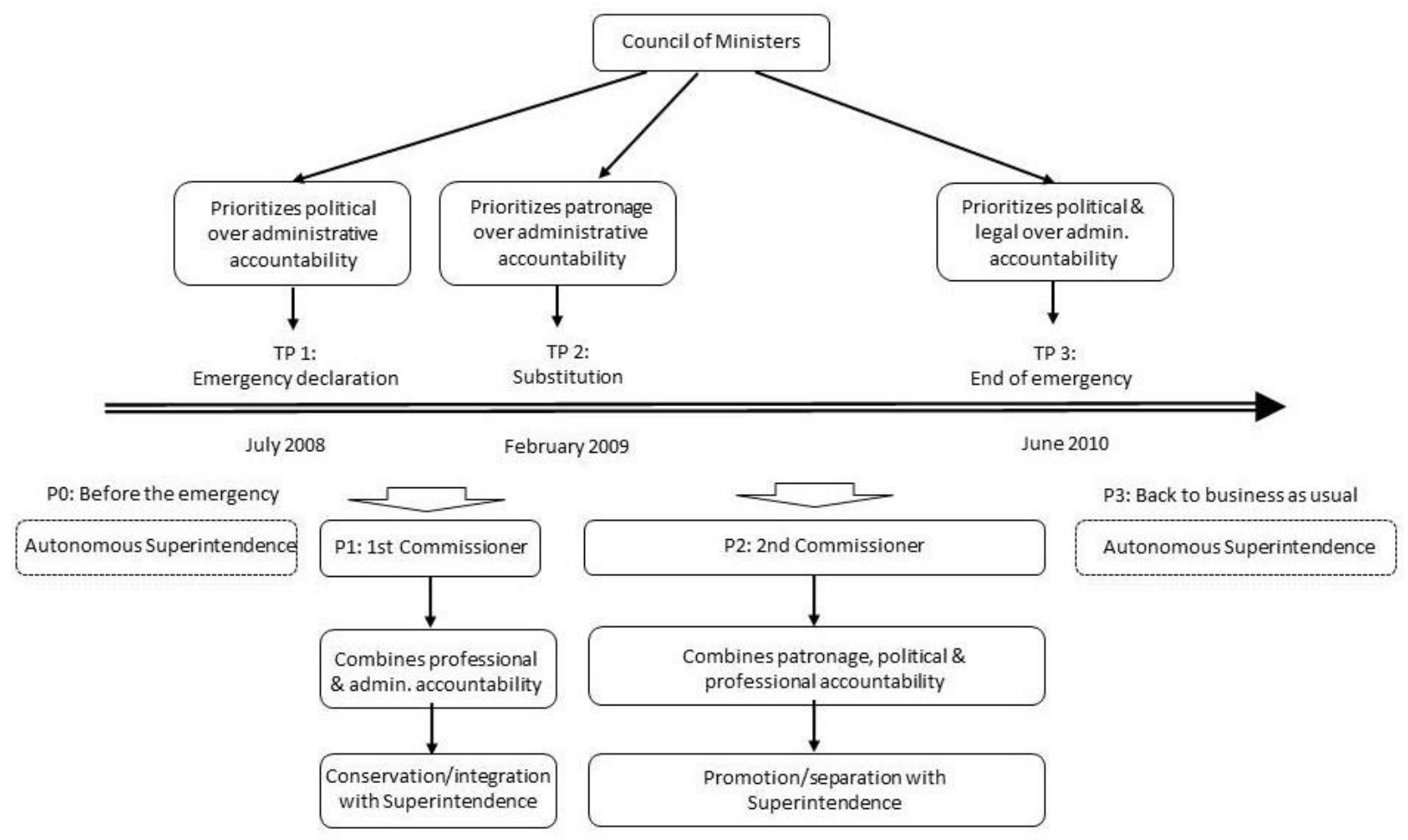

